\title{
ANALYSIS OF IFN- $\gamma$ AND IL-10 LEVELS AS MARKERS OF INFLAMMATION AND RESPONSE THERAPY OF ANTI-TUBERCULOSIS IN MDR LUNG TB PATIENTS
}

\author{
Herni Setyawati ${ }^{1}$, Soedarsono ${ }^{2}$, Yulistiani $^{3}$, Umi Fatmawati ${ }^{4}$ \\ ${ }^{1}$ Master Program of Clinical Pharmacy, ${ }^{2}$ Department of Clinical Pharmacy, Faculty of Pharmacy, ${ }^{3}$ Department of \\ Pulmonology, Faculty of Medicine, Universitas Airlangga, ${ }^{4}$ Department of Pharmacy, Dr. Soetomo Hospital, Surabaya, \\ Indonesia
}

\section{ABSTRACT}

\begin{abstract}
Multidrug-Resistant Tuberculosis (MDR TB) is caused by an organism that is resistant to at least isoniazid and rifampisin, the two most potent TB drug. Immune response to against Mycobacterum tuberculosis infection is related to the function of immunity. The function of interferon- $\gamma$ (pro-inflammatory) is to activate macrophages, to stimulate antimicrobial molecules (to reactive oxygen species and nitric oxide), and to inhibits interleukin-10. Interleukin-10 function is to triggers humoral immunity, to inhibit IFN- $\gamma$. This study aimed to analyze level changes and the correlation with clinical data, also months of MDR TB patients who received standard OAT therapy. This was an observational study using cross sectional design. There were 29 patients who received standard MDR TB OAT therapy from 1-24 months, who met the inclusion criteria. Then, the patients were divided based on duration of the therapy, which are the initial/intensive and advanced phase. The initial phase divided into 2: first one is for 1-4 months therapy's time (5 patients) and the second one is for more than 4-8 months (6 patients). Then, the advanced group divided into two groups again, which are third group with more than 8-16 months (13 patients) and fouth group with more than 16-24 months (5 patients). Then, measured serum concentration IFN- $\gamma, I L-10$ at the start of the study and 4 weeks later with the ELISA method. This research during the period July-December (6 months). IFN- $\gamma$ post concentrations were decreased by $39.14 \pm 139.12 \mathrm{pg} / \mathrm{mL}(\mathrm{p}>0.05)$. The concentration of $I L-10$ was decreased by $33.93 \pm 109.20 \mathrm{pg} / \mathrm{mL}(\mathrm{p}>0.05)$. Based on the TB score bandim method during pre and posts results were 1 patient experienced severity change from severity class 1 to 2 , 1 patient from severity class 2 to 1 , 1 patient remained in severity 2 and 26 patient remained in severity 1 . The results showed that serum IFN- $\gamma$ and IL-10 levels in initial/intensive and advanced phase patients who received MDR TB regiment after four weeks did not changed.
\end{abstract}

Keywords: IFN- $\gamma ;$ IL-10; TB MDR; pre-post

\section{ABSTRAK}

Multidrug Resistand Tuberculosis (MDR TB) disebabkan oleh organisme yang resisten terhadap paling sedikit isoniazid dan rifampisin, dua obat TB yang paling manjur. Respon kekebalan terhadap infeksi Mycobacterum tuberculosis berhubungan dengan fungsi imunitas. Fungsi interferon- $\gamma$ (pro-inflamasi) adalah mengaktifkan makrofag, untuk merangsang molekul antimikroba (untuk spesies oksigen reaktif dan oksida nitrat), dan untuk menghambat interleukin-10. Fungsi interleukin-10 adalah untuk memicu kekebalan humoral, untuk menghambat IFN- $\gamma$. Penelitian ini bertujuan untuk menganalisis kadar IFN- $\gamma$, IL-10 dan data klinis terhadap pasien TB-MDR yang mendapat terapi standar OAT. Penelitian ini adalah penelitian observasional menggunakan desain cross sectional. Terdapat 29 pasien yang mendapat terapi standar MDR TB OAT dari 1-24 bulan, yang memenuhi kriteria inklusi. Kemudian, pasien dibagi berdasarkan durasi terapi, yaitu fase awal/intensif dan lanjut. Tahap awal dibagi menjadi 2: yaitu terapi 14 bulan (5 pasien) dan lebih dari 4-8 bulan (6 pasien). Kemudian, tahap lanjutan dibagi menjadi dua kelompok, yaitu kelompok ketiga > 8-16 bulan (13 pasien) dan kelompok > 16-24 bulan (5 pasien). Kemudian, diukur konsentrasi serum IFN- $\gamma$, IL-10 pada tahap awal penelitian dan 4 minggu kemudian dengan metode ELISA. Penelitian ini berlangsung selama periode Juli-Desember (6 bulan). Konsentrasi pasca IFN-rations menurun sebesar 39,14 $\pm 139,12$ pg/mL ( $p>0,05)$. Konsentrasi IL-10 menurun sebesar 33,93 $\pm 109,20 \mathrm{pg} / \mathrm{mL}(\mathrm{p}>0,05)$. Berdasarkan metode bandim TB skor selama pra dan hasil posting adalah 1 pasien mengalami perubahan keparahan dari tingkat keparahan kelas 1 sampai 2, 1 pasien dari tingkat keparahan kelas 2 sampai 1, 1 pasien tetap dalam tin gkat keparahan 2 dan 26 pasien tetap dalam tingkat keparahan 1. Tidak terjadi perubahan kadar IFN- $\gamma$ dan IL-10 setelah 4 minggu pasca terapi OAT standar TB MDR pada tahap awal terapi dan tahap lanjutan.

Kata kunci: IFN- $\gamma$; IL-10; TB MDR; pre-post

Correspondence: Herni Setyawati, Master Program of Clinical Pharmacy, Jalan Ketintang Wiyata No 38 Surabaya, Indonesia. Phone: +(62)81329502427. E-mail: hernisetyawati285@gmail.com

pISSN:2355-8393 • eISSN: 2599-056x • doi: http://dx.doi.org/10.20473/fmi.v55i4.17318

- Fol Med Indones. 2019;55:268-274 • Received 7 Feb $2018 \bullet$ Accepted 16 Aug 2018

- Open access under CC-BY-NC-SA license • Available at https://e-journal.unair.ac.id/FMI/ 


\section{INTRODUCTION}

MDR-TB is TB caused by Mycobacterium tuberculosis that already resistant to at least two of most effective antituberculosis agents (ATA), isoniazid dan riphampicin. (Mase 2013). MDR-TB regimens are more complex, less effective, more toxic and using more combination of ATA in longer periode (Antonio et al 2013).

Sputum conversion of mycobacterial from positive to negative in tuberculosis patients are considered as important indicator for pharmacological effects of ATA in MDR-TB patients (Holtz et al 2006). Sputum conversion generally occurs in the second month of treatment and is said to be negative if two months later gives a negative sequence. Differences in sputum conversion time can consequence to difference in therapy outcomes of patients despite they receiving the same regimen. It may caused by different immune responses of the patient, eventhought severity of the disease is also determined by the virulence factor of the bacteria, nutritional status and host genetic factors (Adrian et al 2015). The hosts immunity against tuberculosis bacteria is mediated by the presence of cellular immunity, ie, certain cytokines and $\mathrm{T}$ helper cells (Th cells) that play an important role (Kinjo et al 2002).

Those cytokines include IFN- $\gamma$ and IL-10. IL-10 is an anti-inflammatory cytokine that inhibit $\mathrm{T}$ lymphocytes and also inhibit Th1 and Th2. IL-10 acts to inhibit the production of cytokines proinflammatory (IFN- $\gamma$, TNF$\alpha$ and IL-12) and antigen presenting cell, inhibiting the activity of $\mathrm{T}$ lymphocytes by inhibition of molecular expression of MHC II. Therefore IL-10 is an important cytokine because it has an immunoregulatory function to establish a balance between proinflammatory and anti-inflammatory cytokines (Adrian et al 2015).

IFN- $\gamma$ is a major cytokine that activates macrophages, stimulates the production of antimicrobial molecules (osygen reactive species and nitric oxide) in process of Mycobacterium tuberculosis elimination, and stimulates immune cells migration to the area of infection (Cavalcanti et al 2012, Goldsack \& Kirman 2007). It also cntributes to granuloma formation to inhibit the progression of TB (Khan et al 2016). Several studies IFN $\gamma$ and IL-10 indicates various effect and outcmes.

Based on the above description, it is important to do this study. Some study showed existed relationship between levels of cytokines IFN- $\gamma$ and IL-10 in the body with TB progression and ATA outcome (Clifford et al 2015). The combination of those immunologic and clinical markers is expected to predict bacterial progression through proinflammatory and antiinflammatory activity balance, which can prevent relapse after therapy and reduce treatment duration (Clifford et al 2015) This study is expected to provide an overview or profile of proinflammatory and antiinflammatory cytokines levels in patients with pulmonary MDR-TB and can be used as a proposed marker to predict treatment outcome and the prognosis of pulmonary MDR-TB.

\section{MATERIALS AND METHODS}

This study was an observational (non experimental) analytic study, with cross sectional design. The independent variables are the stage of therapy while the dependent variables are serum levels ofIFN- $\gamma$, and IL10. Each phase are divided into 2 groups based on the duration of therapy, such as initial phase: group 1 (duration of 1-4 months), group 2 (duration of therapy 4-8 months), and continuation phase : group 3 (therapy 8-16 months) and group 4 (therapy 16-24 months).

The sample of this study was patients with pulmonary MDR-TB who fulfilled the inclusion criteria: MDR patients aged 15-64 years old, received standard ATA in TB MDR regimen, able to take oral and or enteral and willing to be the subject of this study. Exclusion criteria included patients with HIV test positive, pediatric patients, geriatrics, pregnant and/or breast-feeding women, history of autoimmune diseases and using corticosteroids or other immunosuppressants. The study was conducted in July-December 2017 at TB-MDR units of Dr. Soetomo Hospital, Surabaya, Indonesia.

Samples of this study were counted using below formulation:

$$
\mathrm{n}=\frac{\mathrm{z}_{1-\alpha / 2}^{2} \mathrm{P}(1-\mathrm{P}) \mathrm{N}}{\mathrm{d}^{2}(\mathrm{~N}-1)+\mathrm{z}_{1-\alpha / 2}^{2} \mathrm{P}(1-\mathrm{P})}
$$

where: $1-\alpha=$ confidential interval $(95 \%)$

$\mathrm{Z} 1-\alpha / 2=1.96$

$\mathrm{P} \quad=$ anticipated pulation proportion

(0.50)

$\mathrm{d}=$ absolute precission neede $(0.15)$

$\mathrm{N} \quad=$ total population (55)

Using this formulation, we obtained that total sample minimum are 25 patients. Sampling technique used in this study are consecutive sampling method, we got total sample of 29 patients.

This study has approved by the Ethics Committee of Dr. Soetomo Hospital, Surabaya. All patients included in this study has sign their agrrement in an inform concerned form. Blood serum of patients who met the inclusion criteria were taken and examined their levels 
of IFN- $\gamma$, and IL-10 twice, at the start of this study and four weeks after the first blood count. IFN- $\gamma$, and IL-10 levels were measured using ELISA techniques. To determine the difference between IFN- $\gamma$ and IL-10 pre and post profiles, we use Paired T-test statistical methods was used when the data was normally distributed ( $p>0.05)$, or wilcoxon test non normally distributed data $(\mathrm{p}<0.05)$.

\section{RESULTS}

In this study, total of 29 patients met the inclusion criteria. Baseline characteristics of patients included in this study shown in Table 1.

First, IFN- $\gamma$ and IL-10 levels are determined by making a standard curve of each markers and then followed by measured their absorbance using ELISA. Profile of IFN$\gamma$ and IL-10 levels (averages) and their statistics result are shown in Fig. 1. Its shows that there were no significant difference in averages levels of those markers ( $\mathrm{p}>0.05)$.

Fig. 1 shows profile of IFN- $\gamma$ and IL-10 levels (averages) before and after 4 weeks measurements in every groups of patients. Fig. 2 showed that there were increasing of serum levels of IFN- $\gamma$ and IL-10 between group 1 (1-4 months) and groups 2 (4-8 months). This levels are decrease in patients who were in groups 3 and then increased in group 4. Meanwhile, serum levels of IFN- $\gamma$ and IL-10 are increased after 4 weeks measurements in group 1, while in group 2 and group 3 the serum level were elevated. Serum levels of IFN- $\gamma$ in patients in group 4 were slighly increased while their serum levels of IL-10 are decreased. Non of those are statistically significant.

Fig. 3 shows that the serum levels of IFN- $\gamma$ and IL-10 were tend to increase based on the duration of ATA therapy, while the trendline (trend curve) of serum levels of IFN $-\gamma$ and IL-10 after 4 weeks of pre measurement are lower than their pre-levels but still tend increase. Fig. 4 shows trendline of difference/ changing of serum levels of IFN- $\gamma$ and IL-10 before starting this study and after 4 weeks of MDR TB regimens. It shows that there were a trendline of plateu (non changing) in serum levels of IFN- $\gamma$, where serum levels of IL-10 are tends to decrease.

\section{DISCUSSION}

In our study, our subject are patients who using MDRTB regimen of second-line anti-tuberculosis agnts (ATA) in accordance with ministry of health guideline. In the initiation or intensive phase, MDR-TB regimens are aimed to inhibit the replication of mycobacteria while the continuation phase are aimed to fight persistent bacteria (Jain 2008). Based on Fig. 1, serum levels of IFN- $\gamma$ (proinflammatory) and IL-10 (antiinflammatory) are not significantly decreased $(p>0.05)$ between pre and after 4 weeks of measurement.

Fig. 2 shows that the serum levels of IFN- $\gamma$ and IL-10 at the initial phase of MDR-TB regimens was increased eventhought not statistically significant $(p>0.05)$. This may caused by patient's condition were on the transition stage to conver from smear positive to negative. In this phase, the condition of inflammation can not be controlled or immune response to remove $\mathrm{T}$ cell are not adequate. BTA is still positive indicating the occurrence of replication of Mycobacterium that can not be eliminated by macrophages. Mycobacterium subsequently interacts with CD4 lymphocytes $\mathrm{T}$ cells and releases proinflammatory cytokines. We assumed this is the reason why serum levels of both markers are increased in the early phase. Normally, it takes about 3 weeks after infection before T-helper 1 (Th1) responds by activating macrophages to enhance the bactericidal effect (Jain 2008).

In addition, various literature states the occurrence of drug side effects in the early stages of therapy. The occurrence of side effects of the drug will affect the adherence of drug use. So that in case of drug discontinuation will unilaterally affect the level of cytokines. Gastrointestinal side-related side effects are most common and this often results in treatment changes (Shin et al 2007). Suspected agents for side effects of nausea and vomiting are pyrazinamide, etionamide and PAS (Reviono et al 2014). Ototoxicity may be caused by capreomycin and kanamycin. Patients with DM type 2 comorbidities whose blood sugar are uncontrolled will consequence on increasing of extracellular osmosis pressure increases, the cells are dehydrated so that phagocytosis are decreased followed by penetration of germs intracellular and necrosis occurs. (Mihardja et al 2015). This results in decreasing of bactericidal activity of leucocyte, and so also decrease the effectiveness of ATA. 
Table 1. Baseline characteristics of patients

\begin{tabular}{|c|c|c|c|}
\hline \multicolumn{2}{|c|}{ Patients' characteristic } & \multirow{2}{*}{$\begin{array}{c}\text { Total Patients } \\
19\end{array}$} & \multirow{2}{*}{$\begin{array}{c}\% \\
65.52 \%\end{array}$} \\
\hline Sex & Male & & \\
\hline & Female & 10 & $34.48 \%$ \\
\hline \multirow[t]{5}{*}{ Ages } & $(15-24)$ years & 3 & $10.34 \%$ \\
\hline & $(25-34)$ years & 4 & $13.79 \%$ \\
\hline & $(35-44)$ years & 9 & $31.03 \%$ \\
\hline & $(45-54)$ years & 8 & $27.59 \%$ \\
\hline & $(55-65)$ years & 5 & $17.24 \%$ \\
\hline \multirow[t]{5}{*}{ Sputum conversion } & Not converted after 4 months & 4 & $13.79 \%$ \\
\hline & 1 months & 3 & $10.34 \%$ \\
\hline & 2 months & 13 & $44.83 \%$ \\
\hline & 3 months & 6 & $20.69 \%$ \\
\hline & 4 months & 3 & $10.34 \%$ \\
\hline \multirow[t]{4}{*}{ Resistance } & $\mathrm{H}, \mathrm{R}$ & 12 & $41.38 \%$ \\
\hline & $\mathrm{H}, \mathrm{R}, \mathrm{E}$ & 8 & $27.59 \%$ \\
\hline & $\mathrm{H}, \mathrm{R}, \mathrm{S}$ & 6 & $20.69 \%$ \\
\hline & $\mathrm{H}, \mathrm{R}, \mathrm{E}, \mathrm{S}$ & 3 & $10.34 \%$ \\
\hline \multicolumn{4}{|l|}{ Initial phase regimens } \\
\hline & Z, E, Km, Lfx, Eto, Cs, B6 & 4 & $41.38 \%$ \\
\hline & Z, E, Cm, Lfx, Eto, Cs, B6 & 6 & $48.28 \%$ \\
\hline & Z, Cm, Lfx, Eto, Cs, B6 & 1 & $6.90 \%$ \\
\hline \multicolumn{4}{|c|}{ Continuation phase regimen } \\
\hline & Mfx, Eto, Cs, B6 & 1 & $3.45 \%$ \\
\hline & Z, Lfx, Eto, PAS, B6 & 1 & $3.45 \%$ \\
\hline & Z, Lfk, Eto, Cs, B6 & 3 & $10.34 \%$ \\
\hline & Z, E, Mfx, Eto, Cs, B6 & 1 & $3.45 \%$ \\
\hline & Z, E, Lfx, Eto, Cs, B6 & 12 & $41.38 \%$ \\
\hline \multicolumn{4}{|l|}{ Duration of therapy } \\
\hline & 1-4 months & 5 & $17.24 \%$ \\
\hline & $(>4-8)$ months & 6 & $20.69 \%$ \\
\hline & $(>8-16)$ months & 13 & $44.83 \%$ \\
\hline & $(>16-24)$ months & 5 & $17.24 \%$ \\
\hline \multicolumn{4}{|l|}{ Comorbid } \\
\hline & DM Type 2 & 14 & $48.28 \%$ \\
\hline & DM 2 + Hepatitis & 1 & $3.45 \%$ \\
\hline & No comorbid & 14 & $48.28 \%$ \\
\hline \multicolumn{4}{|c|}{ Patient compliance during the study } \\
\hline & $>80 \%$ & 24 & $82.76 \%$ \\
\hline & $(60-80)$ & 3 & $10.34 \%$ \\
\hline & $<60 \%$ & 2 & $6.90 \%$ \\
\hline \multicolumn{4}{|c|}{ Patient compliance during treatment } \\
\hline & $>80 \%$ & 25 & $86.2 \%$ \\
\hline & $(60-80)$ & 3 & $10.3 \%$ \\
\hline & $<60 \%$ & 1 & $3.5 \%$ \\
\hline \multicolumn{4}{|l|}{ Patients history } \\
\hline & Relaps & 10 & $34.48 \%$ \\
\hline & New cases & 1 & $3.45 \%$ \\
\hline & Therapy failed & 2 & $6.9 \%$ \\
\hline & Drop out & 16 & $55.17 \%$ \\
\hline \multicolumn{4}{|c|}{ BMI (Body Mass Index) } \\
\hline & $\geq 18 \mathrm{~kg} / \mathrm{m}^{2}$ & 18 & $62.07 \%$ \\
\hline & $16-18 \mathrm{~kg} / \mathrm{m}^{2}$ & 7 & $24.14 \%$ \\
\hline & $<16 \mathrm{~kg} / \mathrm{m}^{2}$ & 4 & $13.79 \%$ \\
\hline
\end{tabular}




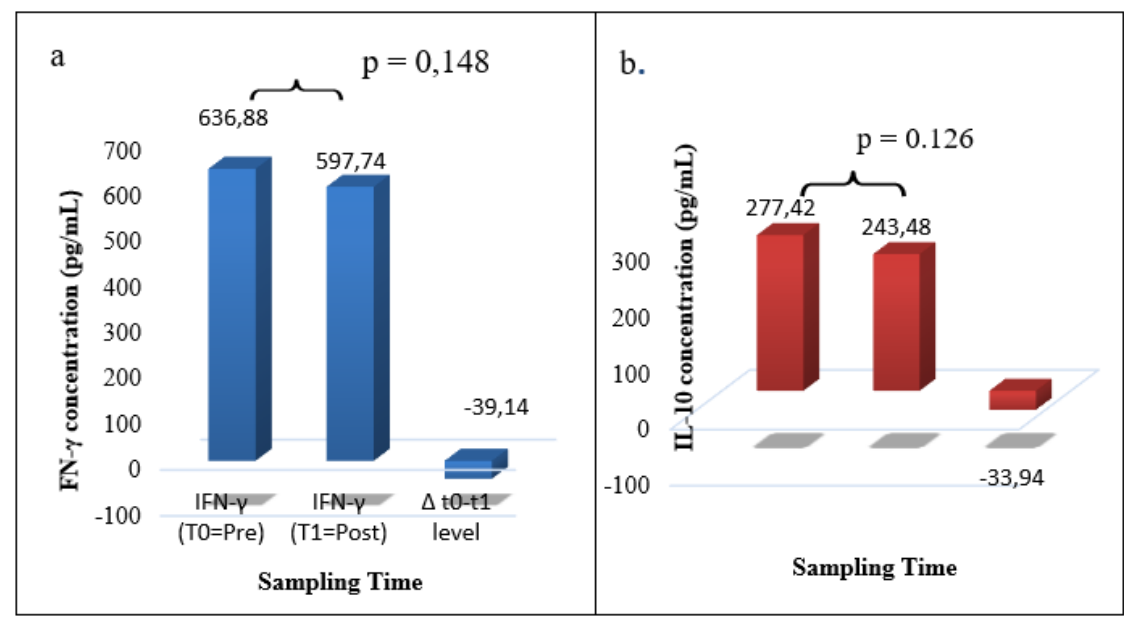

Fig. 1. Serum level average of IFN- $\gamma$ (a) and IL-10 (b) before and after 4 weeks measurements.
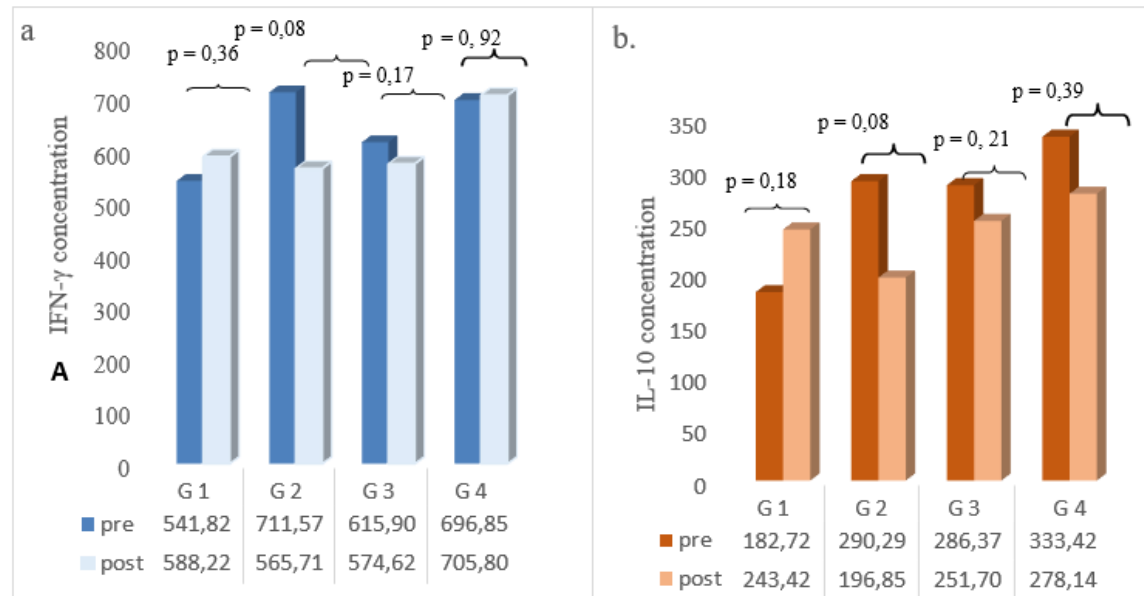

Fig. 2. Serum level average of IFN- $\gamma$ (a) and IL-10 (b) before and after 4 weeks measurements in each groups of patients.
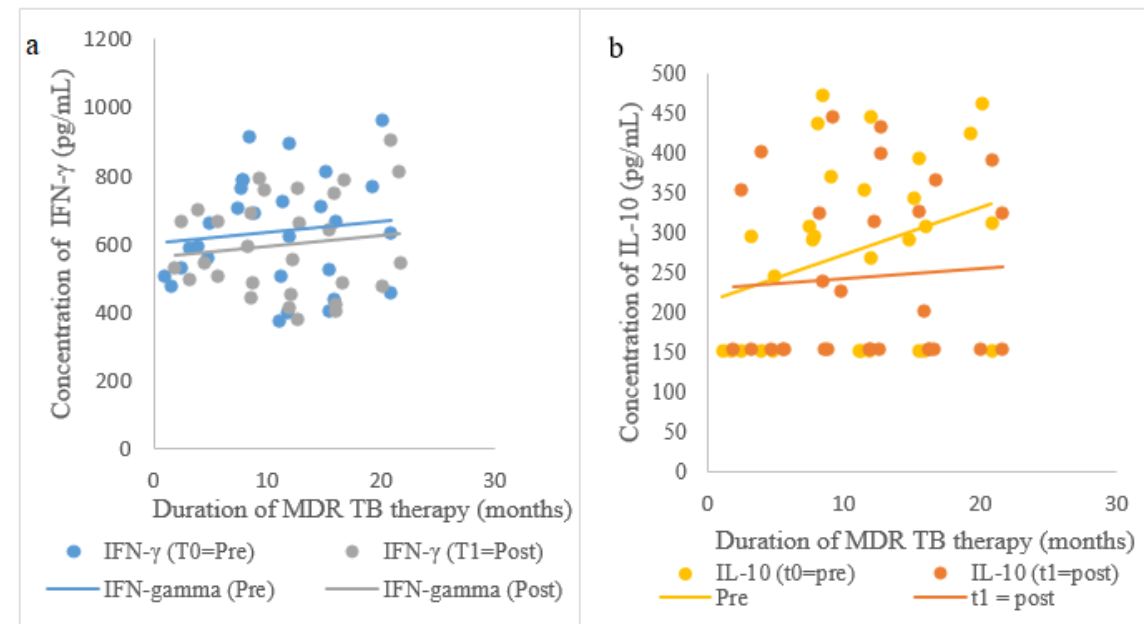

Fig.3. Trendline of serum level average of IFN- $\gamma$ (a), IL-10 (b) before and after 4 weeks measurements. 


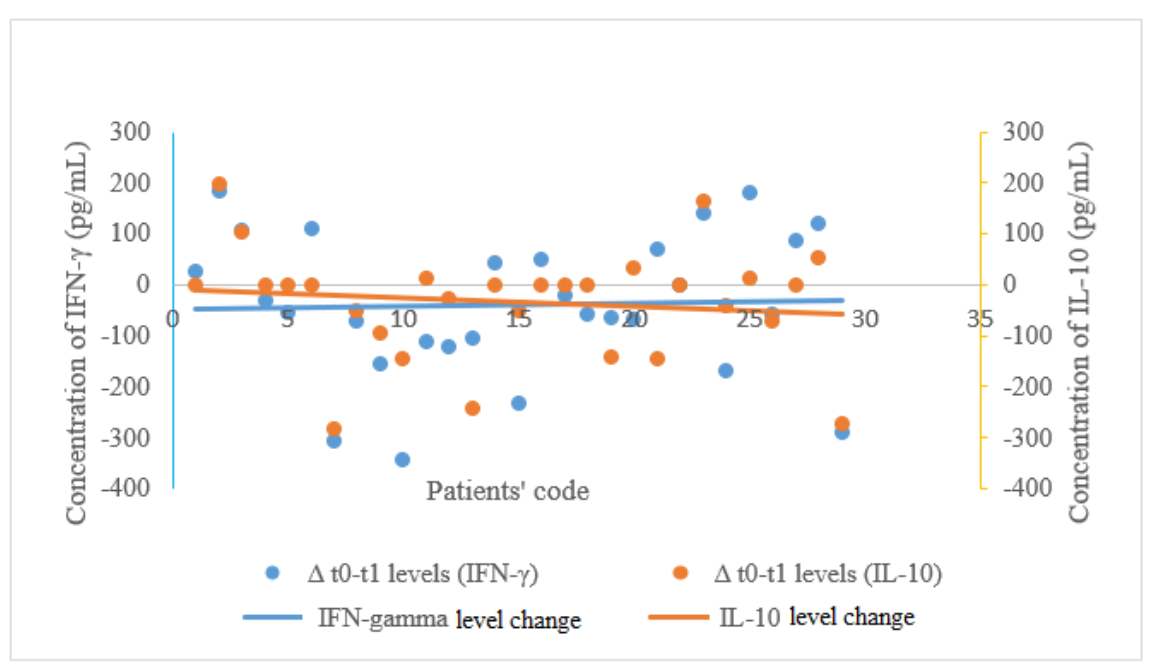

Fig. 4. Trendline of serum level changing (delta) of IFN- $\gamma$ (a) and IL-10 (b) before and after 4 weeks measurements.

As shown in Table 1, total of $48 \%$ patients had DM as comorbid. DM also can changes some pharmacokinetics profile of ATA. ATA efficacy generally depends on the concentration of the drug in the plasma where DM had negative effect. The low levels of ATA in plasma will also increase drugs resistance (Mihardja et al 2015). DM results in the risk of treatment failure, the risk of death, and the relapse of tuberculosis (Baker et al 2011). Patients with DM type 2 will develop immune function defects resulting in impaired of protein metabolism, elevated plasma cortisol levels, increased ketone bodies, acidosis, macrophage phagocytosis and decreased humoral immunity (Mihardja et al 2015). Decreasing the response of humoral immunity will result in a decreased inflammatory response, so levels of IFN- $\gamma$ and IL-10 also decrease.

As shown in Fig. 2, serum levels of IFN- $\gamma$ and IL-10 in the groups 2 are increasing compare to patients in groups 1 , eventhough not statistically significant. Group 2 are patients who had converted sputum test results but still in initiation phase of treatment. This may caused by Post Antibiotic Effect (PAE) of some antibiotics. PAE is delaying effect anti biotics to bacterial growth after exposure of antibiotics, or in other words bacterial growth are still depressed despite the concentration of antibiotics already under the MIC (Minimun Inhibition Concebtration). The presence of PAE in OAT therapy provides an wider dose interval without loss of their therapeutic efficacy. Intervals in addition to reducing drug costs and toxicity may also improve patient compliance. The PAE of the first-line OAT in vitro is 6 to 96 hours. PAE invivo is generally longer than PAE invitro for the same drug combination.
As shows in Fig. 2, serum levels of IFN- $\gamma$ and IL-10 in group 3 patients are decreased compare to patients in group 2 eventhought not satatistically significant. Groups3 is patients who were in first 6 months of continuation phase. This group also showed a very widely vary data, this may be because the patient has undergone the therapy for a very long periode. So that patients feel bored and affect the level of adherence of patients o take the drugs, consequently also affect the levels of IFN- $\gamma$ and IL-10.

As shows in Fig. 2, serum levels of IFN- $\gamma$ and IL-10 in the groups 4 are increasing compare to patients in groups 3 , eventhough not statistically significant. Many factors affecting the efficacy of MDR TB therapy and the resistance factor of Mycobacterium tuberculosis also result in increasing of IFN- $\gamma$ and IL-10 a marker of inflammation in the body eventhought not statistically significant. Some confounding factors, including nutritional status, resistance factors, comorbid factors, prognose of the disease and another factors also influenceso those results. Also, the samples used in this study in every groups were different patients, so the variability profile of patients in each groups will also influence the results of this study.

As shown in Fig 4, the curve of IFN- $\gamma$ and IL-10 serum levels are tends to be plateu. The plateu tendency curve can describe an ongoing inflammatory process, especially in patients with an almost complete continuation phase therapy. In this study, the variation of the measurement result is large enough to get standard deviation, this result in non statistically significant result. Confounding factors such as comorbidity, nutritional status, varying age and adherence may also affect differences in IFN- $\gamma$ and IL- 
10 levels. But this study is expected to be a preliminary study for the next pulmonary MDR-TB study or research by providing an overview or condition profile of inflammatory and therapeutic responses of MDR OAT therapy in patients with pulmonary MDR-TB, specifically in Indonesia.

\section{CONCLUSION}

IFN- $\gamma$ and IL-10 levels in the early and advanced phases as well as next 4 weeks observation after ATA therapy in pulmonary MDR-TB patients showed that there was still an inflammatory process in patients with pulmonary MDR-TB. So, it needs further study related to the influence of comfounding factor in MDR lung TB cases, such as comorbid, sputum conversion status, drug side effects, resistance occurrence and nutritional status of patients.

\section{REFERENCES}

Adrian TBR, Montiel JL, Fernandez G, Valecillo A (2015). Role of cytokines and other factors involved in the Mycobacterium tuberculosis infection.. World Journal of Immunology 5, 16-50

Antonio, Lemoa CM, Matos ED (2013). Multidrugresistant tuberculosis, Spesial article. The Brazilian Journal of Infections Disease 7, 239-246

Baker MA, et al (2011). The impact of diabetes on tuberculosis treatment outcomes: A systematic review. BMC Medicine 9, 1-15

Cavalcanti YVN, Brelaz MCA, Neves JKAL, Ferraz JC, Pereira VRA (2012). Review article: Role of TNFAlpha, IFN-Gamma, and IL-10 in the development of pulmonary tuberculosis. Pulmonary Medicine 2012, 110
Clifford V, et al (2015). Cytokines for monitoring antituberculous therapy: A systematic review. Elsevier XXX, 1-12

Goldsack L, Kirman JR (2007). Half-truths and selective memory: Interferon gamma, CD4(+) T cells and protective memory against tuberculosis. Tuberculosis (Edinb) 87, 465-73

Holtz TH, et al (2006). Time to sputum culture conversion in MDR-TB: Predictor and relationship to treatment ountcome. Annal of Internal Medicine 144, 650-660

Jain SL, et al (2008). Antibiotic treatment of tuberculosis: Old problems. Microbe 3, 285

Khan A, et al 2016. Interferon-Gamma improves macrophages function againts $M$. Tuberculosis in multidrug-resistant tuberculosis patients. Hindawi 110, 2016.

Kinjo Y, et al (2002). Contribution ol IL-18 to Th1 response and host defense against infection by Mycobacterium tuberculosis: A comparative study with IL-12p40. The Journal of Immunolog 169, 323329

Mase S, Chorba T, Lobue P, Castro K (2013). Provisional CDC guidlines for the use and safety monitoring of bedaquline fumarate (Sirturo) for MDR TB. MMWR 62, 1

Mihardja L, Lolong BD, Ghani L (2015). Prevalensi diabetes melitus pada tuberkulosis dan masalah terapi. Jurnal Ekologi Kesehatan 14, 350-358

Reviono, et al 2014. Multidrug resistant tuberculosis (MDR-TB): Tinjauan epidemiologi dan faktor risiko efek samping obat anti tuberkulosis. MKB 46, 189196

Shin S, et al (2007). Adverse reactions among patients being trated for MDT-TBin Tomsk, Russia. Int J Tuberc Lung Dis 11, 1314-1320 